\title{
https://doi.org/10.30853/filnauki.2019.9.83
}

Откидыч Елизавета Вадимовна, Мальцева Ольга Николаевна, Киселева Мария Сергеевна РИТОРИКА В СОВРЕМЕННОМ ВУЗЕ: МЕТОДИКА ОБУЧЕНИЯ СТУДЕНТОВ РАЗНЫХ

\section{НАПРАВЛЕНИЙ ПОДГОТОВКИ}

Статья посвящена разработанной авторами методике преподавания риторики студентам различных направлений подготовки. Представлено подробное описание блоков заданий и модификаций упражнений для аудитории с разным уровнем владения коммуникативной компетенцией. Сделан акцент на универсальности предложенной разработки: она может быть использована в качестве самостоятельного курса риторики или как один из модулей; содержание заданий можно дополнять, менять порядок их выполнения в зависимости от целей освоения дисциплины и индивидуального стиля ведущего преподавателя. Также авторами указывается на возможность использования в предложенной методике инструментов электронно-информационной образовательной среды вуза.

Адрес статьи: www.gramota.net/materials/2/2019/9/83.html

\section{Источник}

Филологические науки. Вопросы теории и практики

Тамбов: Грамота, 2019. Том 12. Выпуск 9. С. 410-417. ISSN 1997-2911.

Адрес журнала: www.gramota.net/editions/2.html

Содержание данного номера журнала: www.gramota.net/materials/2/2019/9/

\section{() Издательство "Грамота"}

Информация о возможности публикации статей в журнале размещена на Интернет сайте издательства: www.gramota.net Вопросы, связанные с публикациями научных материалов, редакция просит направлять на адрес: phil@gramota.net 
УДК $37 ; 342.725 .3$

https://doi.org/10.30853/filnauki.2019.9.83

Дата поступления рукописи: 17.06.2019

Статья посвящена разработанной авторами методике преподавания риторики студентам различных направлений подготовки. Представлено подробное описание блоков заданий и модификаџий упражнений для аудитории с разным уровнем владения коммуникативной компетенцией. Сделан акцент на универсальности предложенной разработки: она может быть использована в качестве самостоятельного курса риторики или как один из модулей; содержание заданий можно дополнять, менять порядок их выполнения в зависимости от иелей освоения дисииплины и индивидуального стиля ведущзего преподавателя. Также авторами указывается на возможность использования в предложенной методике инструментов электронно-информационной образовательной среды вуза.

Ключевые слова и фразы: риторика; коммуникация; методика преподавания; коммуникативная компетенция; индивидуальная образовательная траектория; электронно-информационная образовательная среда.

Откидыч Елизавета Вадимовна, к. филол. н.

Мальцева Ольга Николаевна

Киселева Мария Сергеевна, к. филол. н.

Дальневосточньй федеральный университет, г. Владивосток

vadimovna001@yandex.ru; olgapin_2004@mail.ru; liasic@list.ru

\section{РИТОРИКА В СОВРЕМЕННОМ ВУЗЕ: МЕТОДИКА ОБУЧЕНИЯ СТУДЕНТОВ РАЗНЫХ НАПРАВЛЕНИЙ ПОДГОТОВКИ}

Преподавание риторики в российских вузах ведется уже достаточно давно (с 1994 г.). Включение этой дисциплины в учебные планы мотивировано тем, что «современная риторика решает задачу формирования личности человека через развитие его речевых способностей и повышение речевой эрудиции» [9, с. 364-365].

Актуальность представленного исследования обуславливается продолжающимся педагогическим поиском эффективных методик преподавания разных дисциплин (в том числе и «Риторики») в условиях корректировок образовательных стандартов и стремления вузов к универсализации и оптимизации, появления новых информационных технологий, изменения состава групп учащихся и перечня навыков, которыми уже обладают современные студенты и которые у них ещё необходимо сформировать. Этой теме посвящено много публикаций $[1-3 ; 8 ; 11 ; 13-15]$. Научная новизна же данной работы заключается в разработке авторской методики преподавания риторики, универсальной и адаптивной для любых категорий вузовских учащихся, ориентированной на современные образовательные тренды - цифровизацию и игрофикацию.

Цель представленной работы - дать комплексное описание методики модульного преподавания курса «Риторика», созданной авторами. Для этого были решены следующие задачи: изучена основная исследовательская литература по рассматриваемому вопросу; выбрана образовательная среда, по своим условиям подходящая для достижения поставленной цели (такой средой и стал Дальневосточный федеральный университет, в котором по широкому спектру специализаций и направлений обучаются (очно, заочно и дистанционно) студенты разных возрастов и стран); в течение нескольких лет (с 2016 по 2018 гг.) осуществлена апробация комплекса методических подходов к преподаванию «Риторики» с его ежегодной корректировкой в зависимости от получаемых промежуточных результатов; на имеющейся теоретической и практической базе окончательно сформирована концепция универсального авторского курса «Риторика».

В некоторых методических статьях по рассматриваемой теме представлен опыт преподавания риторики с ориентацией на определенное направление подготовки (например, реклама, связи с общественностью, журналистика) [2; 15]. Такой подход предполагает овладение студентами до изучения курса риторики некоторыми профессиональными навыками и умениями. Однако анализ учебных планов вузов показывает, что чаще всего рассматриваемая дисциплина включается в программу 1-2 курса бакалавриата, когда студент только начинает осваивать профессию, поэтому, по нашему мнению, в разработке материалов для курса необходимо учитывать не столько направление подготовки, сколько исходный уровень коммуникативной, в частности риторической, компетенции и психологические особенности студентов, в смешанных группах (российские и иностранные студенты) - еще и особенности национального риторического идеала. Впрочем, это касается только так называемой общей риторики, а не преподавания частных риторик: педагогической, судебной, политической.

В результате освоения дисциплины у студента должна быть сформирована риторическая компетенция, которая является частью коммуникативной компетенции. Под риторической компетенцией мы, вслед за Л. Н. Горобец, понимаем «способность осознанно создавать, производить и рефлексировать авторско-адресный текст речевого/риторического жанра в соответствии с целью и ситуацией публичной речи» [6, с. 215]. Уже на 1 курсе студент сталкивается с необходимостью готовить сообщения разных жанров и выступать с ними перед слушателями, но довольно большая часть первокурсников не могут этого сделать. Курс «Риторика» помогает студентам повысить уровень владения ораторскими навыками, что положительно влияет на их коммуникативную компетенцию, включенность в учебный процесс и участие во внеаудиторной деятельности [7].

В Дальневосточном федеральном университете риторика традиционно преподавалась студентам, изучающим журналистику, рекламу и связи с общественностью, политологию, международные отношения. Однако 
в последние годы круг направлений, в учебные планы которых был введен этот курс, значительно расширился (естественнонаучные, технические; бакалавриат, магистратура, программы дополнительного образования). Надо также отметить, что студенты, изучающие другие дисциплины, - «Русский язык и культуру речи», «Русский язык в профессиональной коммуникации», «Межкультурную коммуникацию» и под., - часто просят уделить на занятиях внимание и риторическому аспекту, что требует от преподавателя дополнительных методических усилий по анализу имеющихся в его распоряжении пособий по риторике и отбору подходящих упражнений. Все это поставило перед авторами данной статьи интересную методическую задачу - создать курс риторики, который можно было бы легко трансформировать для определенной студенческой аудитории, а также использовать возможности, предоставляемые электронно-информационной образовательной средой.

Отталкиваясь от наиболее известных пособий по практической риторике $[4 ; 5 ; 10 ; 12]$, был разработан авторский курс «Риторика». Он отличается универсальностью и гибкостью, вырабатывает навыки и умения, необходимые любому современному специалисту. В зависимости от учебного плана, конкретного направления курс может быть использован и как самостоятельная дисциплина, и как один из модулей других дисциплин (например, «Русский язык и культура речи», «Русский язык в профессиональной коммуникации», «Основы делового общения», «Риторика и основы речевого общения», «Риторика и академическое письмо», «Межкультурная коммуникация» и т.п.).

Концепция данного курса универсальна: он состоит из 5 взаимосвязанных частей, каждая из которых дополняет предыдущую и конструируется преподавателем в зависимости от уровня/направления/состава группы студентов; может использоваться как вместе с занятиями лекционного типа (в традиционном или онлайнформате), так и без них.

Композиция расположения частей циклична, причем предлагаемую последовательность можно повторять какое угодно количество раз, усложняя задания, углубляя анализ:

1 блок - диагностический: взгляд на себя как на оратора, оценка своего исходного уровня риторической компетенции;

2 блок - анализ своих и чужих невербальных сигналов;

3 блок - умение строить и произносить подготовленные и импровизационные выступления (на материале протокольно-этикетных выступлений);

4 блок - совершенствование и закрепление риторических навыков (на материале убеждающих выступлений);

5 блок - завершающий: самооценка достигнутого уровня риторической компетенции, определение направления дальнейшего развития риторических навыков.

Упражнения каждого блока условно делятся на творческие и аналитические, они дополняют друг друга, задействуют разные типы восприятия, подразумевают как групповую, так и индивидуальную работу, т.е. происходит комплексная отработка основных практических навыков.

Авторы не выделяли в отдельный блок работу над фонационными характеристиками голоса. Но упражнения на отработку фонационного дыхания и постановку голоса, конечно же, необходимы начинающему оратору. Их можно выполнять в начале каждого занятия, но основная отработка должна выполняться студентами самостоятельно во внеаудиторное время. При необходимости преподаватель подбирает студенту упражнения для устранения индивидуальных фонационных недочетов. В качестве контроля можно перед блоком 3 провести игровой конкурс «Лучший диктор».

Далее будут подробно рассмотрены все блоки, охарактеризованы основные навыки, вырабатываемые в процессе их прохождения, предложены варианты формулировок заданий и их комбинаций в зависимости от потребностей и уровня групп и количества входящих в них студентов.

\section{Блок 1. «Взгляд на себя как на оратора»}

Эта часть является вводной ко всему курсу, ее цель - диагностика уровня сформированности коммуникативной компетенции студентов, в том числе первичных ораторских навыков. Такая информация необходима не только преподавателю, но и студенту, ведь формирование индивидуальной образовательной траектории происходит при включенности в процесс всех субъектов обучения.

Работа над упражнениями этого блока требует активной позиции преподавателя, поскольку он должен помочь студентам не только усвоить основные теоретические и практические навыки, но и преодолеть типичные психологические проблемы начинающего оратора (боязнь аудитории: страх случайной оговорки, неумение донести мысль и привлечь внимание, забывчивость и проч.). Поэтому особенно важной является доброжелательная и доверительная атмосфера на занятии. Если учащийся отказывается выполнять какую-либо работу в аудитории, ему предлагается прийти на консультацию и отработать упражнение (в отдельных случаях не стоит настаивать на публичном выступлении, поскольку для небольшого числа учащихся сам выход к доске является большим стрессом; однако даже такой страх не должен быть помехой к выполнению предлагаемых заданий). Один из возможных вариантов выполнения задания в таком случае - использование видео, записанного самим студентом и присланного преподавателю или выложенного в закрытую интернет-группу.

Блок начинается с самопрезентации преподавателя и курса. Важно показать пример, продемонстрировать, как осуществляется этот вид речевой деятельности, а затем обсудить с аудиторией, где и с какой целью используется самопрезентация (как в официальных, так и в неофициальных ситуациях), поскольку каждый обязательно сталкивался или еще столкнется с ситуацией, когда ему нужно будет кратко рассказать о себе малознакомым людям. После вступления группа переходит к выполнению первого задания.

Задание 1. «Самопрезентация». Преподаватель просит студентов за 10 минут (если группа сильная, то время на подготовку не даётся) подготовить полуимпровизационное информационное выступление - 
рассказ о себе на 1 минуту (в зависимости от количества учащихся, а также их настроя время выступления может быть увеличено до 1,5 минут или сокращено до 0,5 минуты). Разрешается сообщить любую информацию, которая, на взгляд студента, будет интересна аудитории и представит его в выгодном свете. Тезисы можно записать, при произнесении речи разрешается подглядывать в «шпаргалку», но не читать.

Данное упражнение можно усложнить, предложив учащимся: 1) составить «самопрезентацию в цифрах» (т.е. чтобы рассказ о себе содержал максимальное количество цифр); 2) включить в выступление случайные слова, данные преподавателем и не связанные друг с другом (слова студент получает непосредственно перед речью, количество слов зависит от уровня аудитории); 3) сосредоточиться на своих профессиональных успехах в выбранной области; 4) рассказать о своей роли в группе учащихся; 5) рассказать о своих жизненных целях и задачах и проч.

Преподаватель обращает внимание аудитории, что при подготовке выступления необходимо учесть следующие пункты:

- речевой этикет (при необходимости объясняется это понятие);

- наличие композиционной рамки выступления (наличие вступления и заключения);

- временной регламент (необходимо рассказать о важности этого критерия, обсудить с группой, почему следует максимально строго придерживаться регламента, когда его можно нарушать).

Преподаватель обязательно называет 1 минус и 1 плюс каждого выступления. Лучше это делать сразу, а не подводить итог в конце. Остальные учащиеся также выборочно высказываются, называя плюсы выступлений своих товарищей (на минусах внимание лучше не заострять, их обозначает только преподаватель в максимально корректной форме). Развернутая характеристика выступлений не требуется, но небольшой комментарий необходим.

На отработку навыков выстраивания и подготовки небольшого выступления, преодоление боязни аудитории и рассчитано первое задание. Также оно позволяет преподавателю выявить самые яркие сильные и слабые стороны каждого студента, а учащимся - оценить свои ораторские навыки, с которыми они входят в дисциплину, определить, над чем им предстоит особо поработать.

Задание 2. «Обсуждение качеств идеального оратора». Студенты делятся на группы по 5-8 человек. С помощью мозгового штурма в течение 5-7 минут им необходимо выявить и обосновать качества, которыми должен обладать идеальный оратор (6-8 пунктов). Далее делегат от каждой группы зачитывает эти качества и к каждому даёт краткое пояснение.

На основании ответов групп преподаватель формирует на доске сводный список качеств идеального оратора (6-8). Пункты данного списка наносятся на одну из осей координат, а на другой ставятся цифры от 0 до 5 (допускается сделать шаги более дробными, например, от 0 до 10), где 0 обозначает «абсолютно не владею», 1 - «почти не владею», 2 - «немного владею», 3 - «владею удовлетворительно», 4 - «владею хорошо», 5 - «владею отлично».

Каждый студент в тетради строит график, в котором самостоятельно (на основании предыдущего опыта, самопрезентации и обсуждения в группе) оценивает свои ораторские качества по заданной шкале. По желанию графики можно обсудить в аудитории.

Оформление графиков, а также качества оратора и их последовательность в каждой группе могут различаться. В дальнейшем в конце каждого занятия (или блока занятий) студенты должны обращаться к построенному графику и отмечать на нём те пункты, по которым они продвинулись (не обязательно переходить сразу между делениями, возможны и промежуточные шаги), а также те позиции, над которыми необходимо работать упорнее. Эта работа должна стимулировать самостоятельную учебную деятельность студента даже после успешного прохождения дисциплины.

Задание 3. «Анализ чужого выступления». В качестве домашнего задания студентам предлагается проанализировать видео выступления Марии Максаковой на заседании в Государственной Думе 17 июня 2014 г. [16]. Необходимо выявить и записать в тетрадь плюсы и минусы выступления, распределяя их по двум группам: плюсы самого оратора и преподнесения речи (исходят из качеств оратора), плюсы собственно речи (т.е. произносимого текста); минусы оратора, минусы речи (текста). Найденные плюсы и минусы могут выходить за рамки списка качеств идеального оратора и коммуникативных качеств речи. Затем сделанные наблюдения обсуждаются в аудитории, поскольку для начинающего оратора (как, впрочем, и для опытного) бывает очень полезным понаблюдать за реализацией чужого выступления, чтобы отметить типичные ошибки или, наоборот, особые приёмы, которые стоит взять на вооружение и сформировать свой ораторский образ.

Специально предлагается выступление, многим составляющим которого сложно дать однозначно положительную или отрицательную оценку. Преподаватель может выбрать любой другой пример, который, на его взгляд, будет продуктивнее для анализа, представить однозначно положительный и/или отрицательный примеры и проч.

Таким образом, первый блок направлен на выработку навыков стихийного выступления и опыта борьбы с ораторским стрессом, формирует умение строить выступление по заданным критериям, анализировать своё и чужое выступление, подмечая сильные и слабые стороны, знакомит с жанром информационного выступления.

\section{Блок 2. «Анализ своих и чужих невербальных сигналов»}

Эта часть опирается на знания и навыки, полученные в первом блоке, в ней выступление рассматривается как сложный процесс, включающий в себя две основные составляющие: вербальную и невербальную. Именно на последней и делается акцент, поскольку выступающему зачастую трудно (а порой и невозможно) адекватно оценить транслируемый им невербальный код (жесты, мимика, осанка, одежда и проч.). Начинающие 
ораторы либо вовсе забывают о невербалике, либо уделяют ей слишком много внимания, от чего в обоих случаях страдает качество выступления.

Задача упражнений данного блока - приучить учащихся наблюдать за своими и чужими невербальными сигналами, уметь их анализировать и грамотно интерпретировать, адекватно сопровождать ими своё выступление, избегая неконгруэнтности. Данный блок начинается с домашнего задания и его проверки в группе.

Задание 1. «Анализ невербалики по видео». Сначала учащимся предлагается найти и выписать в тетрадь определение и классификацию невербальных сигналов (если эта информация не была рассмотрена на лекции). Затем - посмотреть видеоматериал (к/ф «Операция “Ы” и другие приключения Шурика», новелла «Наваждение», сцена «Экзамен») [18] без звука, отметить все увиденные невербальные сигналы и охарактеризовать процесс общения героев, опираясь только на информацию, полученную из невербального канала. Затем необходимо соотнести эти сигналы с речью персонажей. Форма выполнения задания может быть как устной, так и письменной (зависит от уровня группы). Во втором случае можно предложить студентам заполнить таблицу (Рис. 1).

\begin{tabular}{|c|c|c|c|}
\hline Герой & $\begin{array}{c}\text { Невербальный } \\
\text { знак (сигнал) }\end{array}$ & $\begin{array}{c}\text { Функция (информация, } \\
\text { которую несёт невербальный сигнал) }\end{array}$ & $\begin{array}{c}\text { Фраза(ы) (которой(ыми) сопровождается } \\
\text { невербальный сигнал) и интонация }\end{array}$ \\
\hline & & & \\
\hline & & & \\
\hline
\end{tabular}

Рисунок 1. Вспомогательная таблиц̧а для анализа видеоматериала по теме «Невербальные средства общения»

Преподаватель волен выбрать любой другой отрывок из кинофильма или другой русскоязычный кинофильм (возможно, студенты сами подскажут, какой эпизод они хотели бы проанализировать), где ярко проявляется невербалика героев. В зависимости от уровня аудитории преподаватель выбирает: просмотреть весь отрывок сразу и затем дать слово студентам или пускать видео небольшими частями, чтобы учащиеся сразу их комментировали.

Если в группе обучаются студенты из других стран, то можно предложить им рассказать о знаках невербальной коммуникации, которые отличаются от используемых русскими.

Задание 2. «Моё невербальное поведение». После разбора видео студентам предлагается выполнить в аудитории несколько упражнений для оценки собственных невербальных сигналов и сигналов коммуникативного партнёра.

А) Упражнение «Зеркало». Группа делится на пары, в каждой паре один - говорящий, второй - «зеркало». Задача «зеркала» - задавать несложные вопросы, чтобы говорящий мог составить простой развёрнутый ответ, и «отзеркаливать» все движения говорящего: позу, жесты, если возможно - мимику и т.п.; задача говорящего - отвечать на вопросы «зеркала» и вести себя при этом максимально естественно. Затем напарники меняются ролями. Происходит обсуждение и анализ увиденного.

Б) Можно предложить другое, более сложное упражнение - «Бегемот». К доске выходят 2 добровольца и получают карточку с диалогом, в котором пронумерованы реплики (1 и 2) соответственно количеству участников диалога и даны ремарки с указанием эмоции. Задача участников - прочитать диалог, строго соблюдая эмоциональность реплики, но при этом на ходу заменять слова цифрами. Задача аудитории - внимательно слушать и в конце восстановить коммуникативную рамку диалога: суметь ответить на вопросы, что происходило, как относились участники коммуникативного акта друг к другу и как менялось их отношение по ходу общения (в качестве варианта можно попросить студентов давать комментарии после каждой реплики или каждой пары/группы реплик).

Диалог:

1: (Радостно) Здравствуйте! У вас есть бегемоты? (Читать: Радостно: 58 ! 4640 35?)

2: (Равнодушно) Здравствуйте, нет. (Читать: Равнодушно: 58, 346.)

1: (Удивлённо) Совсем нет? (И так далее)

2: (Недоумевающе) Совсем нет. (И так далее)

1: (С надеждой) Ну, может быть, всё-таки посмотрите?

2: (Раздражённо) Смысл искать, если у нас нет бегемотов?

1: (Умоляюще) Ну, пожалуйста, всего один маленький бегемотик!

2: (С угрозой) Я повторяю. У нас. Нет. Никаких. Бегемотов!

1: (Печально) Значит, нет?

2: (Агрессивно) Девушка / молодой человек, это аптека! (Примирительно) Возьмите лучше что-нибудь от головы.

В) Упражнение «Крокодил». Студенты самостоятельно или с помощью преподавателя разбиваются на группы по 5-8 человек. Каждая группа получает задание: после 5-минутной подготовки выйти к доске и показать какую-либо ситуацию без слов и звуков, остальные группы должны эту ситуацию угадать. Примерные ситуации, которые даются для изображения: переполненный автобус, перемена в школе, премьера популярного фильма, рынок, очередь в поликлинике, студент не готов к экзамену и др.

Тип упражнения выбирается в зависимости от группы, но обязательно в финале требуется комментарий преподавателя, который выделит яркие положительные и отрицательные стороны невербального поведения каждого учащегося, скорректирует отзывы студентов друг о друге. 
Задание 3. «Моё видеовыступление». Студенты разбиваются на пары. Каждый должен записать своё 3-5-минутное (в зависимости от уровня группы) выступление на видео, а затем посмотреть это видео, проанализировать себя как оратора и отправить видео на анализ напарнику. В итоге у каждого видео будет два разбора: самого участника записи и стороннего наблюдателя. Такое задание помогает увидеть себя со стороны, обозначить свои сильные и слабые стороны, определить адекватность самооценки, развить навыки объективного анализа чужих выступлений. Если у группы имеется свое сообщество в одной из социальных сетей, видео можно выкладывать туда и там же размещать его разбор.

Второй блок продолжает работу по снятию зажимов оратора, готовит студентов к выступлению не только перед живой аудиторией, но и перед камерой, способствует выработке навыков объективного анализа своего и чужого выступления, помогает гармонизировать вербалику и невербалику.

Блок 3. «Умение строить и произносить подготовленные и импровизационные выступления (на материале протокольно-этикетных выступлений)»

С данным типом выступлений так или иначе сталкиваются все люди в профессиональной и личной сфере. Третий блок призван выработать навыки построения и произнесения соответствующих текстов. Мы предлагаем отрабатывать их на примере поздравительной речи, которая, как правило, невелика по объёму, композиционно несложна, предполагает творческий подход, а также приветствует юмор. Всё это позволяет формировать и отшлифовывать первичные навыки публичной речи в относительно непринуждённой обстановке, которая для начинающего оратора исключительно важна.

В зависимости от уровня группы и количества предоставленных учебным планом часов преподаватель решает, каким будет Задание 1: a) конспект теории по теме «Поздравительная речь»; б) работа с текстом протокольно-этикетного выступления, предложенным преподавателем, и выявление его основных особенностей. Во втором случае целесообразно дать студентам готовый текст поздравительного выступления, в котором перепутаны порядок предложений и абзацы. Восстанавливая исходный замысел автора, учащиеся легче выводят основные правила создания текстов данного жанра.

Задание 2. «Протокольно-этикетное выступление жанра “поздравление”». Полученную теорию студенты должны уметь применять на практике, поэтому они готовят дома поздравление, приуроченное к малоизвестному (это поможет им написать текст самостоятельно, а не скачать из Интернета) празднику. Адресатом является группа учащегося, поэтому одновременно оттачиваются и навыки адаптации материала для конкретной аудитории. Желательно, чтобы выбранный праздник как-то соотносился с аудиторией учащихся, был с ними связан, актуален для них. Регламент выступления - от 1 до 2 минут (в зависимости от уровня группы и количества учащихся). При этом мы рекомендуем: 1) выступления короче 1 минуты не засчитывать (т.к. студент должен написать и произнести полноценный текст, а не пару высказываний); 2) требовать свободного произнесения текста, а не чтения (в отдельных случаях разрешается подглядывать в заранее приготовленные тезисы).

Каждый студент выходит к доске и произносит поздравительную речь. После её завершения все учащиеся (в т.ч. и сам выступивший) вместе с преподавателем оценивают выступление, заполняя специальную карточку (Рис. 2).

\begin{tabular}{|c|c|c|c|c|c|c|c|}
\hline $\begin{array}{c}\text { Соответствие } \\
\text { теме }\end{array}$ & $\begin{array}{c}\text { Содержание } \\
\text { выступления }\end{array}$ & $\begin{array}{c}\text { Композиция } \\
\text { выступления }\end{array}$ & $\begin{array}{c}\text { Использо- } \\
\text { вание фраз } \\
\text { речевого } \\
\text { этикета }\end{array}$ & $\begin{array}{c}\text { Невер- } \\
\text { бальные } \\
\text { сигналы }\end{array}$ & $\begin{array}{c}\text { Визуальный } \\
\text { контакт }\end{array}$ & $\begin{array}{c}\text { Эмоцио- } \\
\text { нальность }\end{array}$ & $\begin{array}{c}\text { Наличие/ } \\
\text { отсутствие } \\
\text { чтения }\end{array}$ \\
\hline & & & & & & & \\
\hline
\end{tabular}

Рисунок 2. Вспомогательная таблица для анализа видеоматериала по теме «Поздравительное выступление»

Количество баллов, которым может быть оценён каждый критерий, остаётся на усмотрение преподавателя, но мы рекомендуем остановиться на 3-балльной шкале, т.к. это первое подготовленное выступление, и слишком строгая оценка может демотивировать ряд студентов, особенно не очень уверенных в себе.

После того как выступили все, группа на основании заполненных таблиц подводит под руководством преподавателя (оно необходимо, чтобы обеспечить объективность оценок) общие итоги. Выявляются самые распространенные сильные и слабые стороны, лучшие ораторы на данном этапе. Также каждый студент может посмотреть, как товарищи оценили его выступление, узнать, где у него были успехи и где он допустил промахи.

По согласованию со студентами можно сделать аудио- или видеозапись их выступлений и отправить для анализа после занятия. Этот аналитический (посткоммуникативный) этап не менее важен, чем этап подготовки (докоммуникативный) и произнесения выступления (коммуникативный), им ни в коем случае нельзя пренебрегать. Ведь именно во время него оратор может в спокойной обстановке детально оценить своё выступление.

Задание 3. «Импровизация». Студенты, как правило, убеждаются, что произнести подготовленное протокольно-этикетное выступление не так сложно. Однако в жизни часто приходится сталкиваться именно с неподготовленными, импровизационными публичными выступлениями. Поэтому навык словесной импровизации в заданном жанре весьма важен и полезен. Предлагаемые задания нацелены на отработку данного навыка.

Студент вытягивает карточку, поворачивается к аудитории и громко читает сформулированное в ней задание, а затем сразу же произносит импровизационное протокольно-этикетное выступление от 30 секунд 
до 1,5 минут (в зависимости от уровня группы). Времени на подготовку не даётся! Чтобы усложнить задание, преподаватель может добавить в карточки 1 или 2 слова, которые никак не связаны с темой речи, но обязательно должны прозвучать в любой части выступления.

Примерные задания для импровизации:

1. Вам нужно поздравить друзей со взятой ипотекой. Слово, которое обязательно должно прозвучать: ЛЬДИНА.

2. Вам нужно произнести короткую речь на закрытии слёта байкеров. Слово, которое обязательно должно прозвучать: КОТЁНОК.

3. Вам нужно от лица всех жителей Земли поприветствовать вернувшихся космонавтов. Слово, которое обязательно должно прозвучать: ГУБКА.

4. Вам нужно произнести короткую речь на закрытии конкурса красоты. Слово, которое обязательно должно прозвучать: МУРАВЬЕД.

5. Вам нужно произнести краткий тост на новогоднем корпоративе. Слово, которое обязательно должно прозвучать: КАРТОШКА.

Задание 4. «Похвала». Если для дисциплины отведено достаточное количество времени, то, чтобы дать студентам возможность отработать допущенные в ходе предыдущего выступления ошибки или, наоборот, закрепить успех, следует обратиться ещё к одному несложному жанру протокольно-этикетных выступлений похвале. Однако при этом задача немного усложняется: преподаватель ставит цель похвалить какое-либо негативное явление (пробки, сломанный лифт, отключившийся Интернет, маленькую зарплату и проч.). Поиск в нём позитивных черт позволит учащимся потренироваться в нахождении аргументов для эффективного убеждения и таким образом подготовит почву для перехода к самому сложному типу публичных вступлений - убеждающему.

Данное задание можно оценивать по принципу зачет/незачёт, а можно снова применить 3-балльную систему оценки, чтобы явно отметить прогресс или регресс учащихся.

Третий блок формирует у студентов жанровое мышление, основные навыки анализа аудитории и работы с ней, знакомит с методикой подготовки выступления, развивает умение импровизировать, позволяет получить более широкий отклик на их выступление, способствует формированию. Благодаря тому, что большинство заданий содержит в себе и юмористический компонент, в аудитории создаётся позитивная атмосфера, настраивающая на самореализацию, позволяющая преодолеть боязнь выступлений и конструктивно критиковать / воспринимать критику.

Блок 4. «Совершенствование и закрепление риторических навыков (на материале убеждающих выступлений)»

Данный блок суммирует все навыки и знания учащихся, полученные в трёх предыдущих. Убеждающие выступления считаются самым сложным видом публичных речей. Они требуют хорошего владения не только базовыми, универсальными, но и специфическими навыками оратора. Сюда входит и умение логично выстраивать свою речь, делать её непротиворечивой, и способность корректно ставить тезис и подбирать к нему аргументы, причём в соответствии с аудиторией, перед которой будет произнесено выступление, а также навык правильного расположения аргументов.

Задание 1. «Аргументащия, её виды». Учащимся необходимо самостоятельно найти теорию по аргументации и кратко ее законспектировать (либо эту теорию представляет преподаватель на соответствующей лекции), а затем посмотреть фрагмент из кинофильма «Запах женщины» (реж. Мартин Брест, финальная сцена «Выступление полковника перед дисциплинарной комиссией») [17] и ответить на вопросы (письменно или устно, на усмотрение преподавателя): каков был тезис выступления, убедил ли оратор вас в своей точке зрения, какие способы и правила эффективной аргументации использовал персонаж?

Задание 2. «Подбор аргументов». Студенты разбиваются на группы по 4-9 человек. В зависимости от уровня группы задание можно модифицировать.

А) Все группы получают одинаковое задание: за 10-15 минут составить небольшое убеждающее выступление на определённую тему (например, «N причин поступить на нашу специальность» или «N причин поехать в отпуск в Антарктиду» и т.п.). Принципиально важно обратить внимание на следующие критерии: соответствие композиции убеждения (тезис во введении - аргументация в основной части - вывод в заключении); обязательная максимально чёткая формулировка тезиса; наличие не менее трёх сильных аргументов в поддержку тезиса. За время, отведённое на выполнение задания, студентам необходимо: с помощью мозгового штурма найти максимальное количество аргументов, выбрать из них три самых сильных, расположить их в таком порядке, который сделает аргументацию максимально эффективной, придумать введение, включающее тезис, и заключение, содержащее вывод, быстро освоить текст, выйти и представить его аудитории.

Б) Каждая группа получает обобщенный портрет аудитории: молодые мамы, студенты технических специальностей, студенты гуманитарных специальностей, бизнесмены, пенсионеры и проч. - и одинаковую тему выступления, например «Откажитесь от мяса!». Задача состоит в том, чтобы подобрать как можно больше сильных аргументов для предложенного тезиса с учётом характеристик полученной аудитории. Так студенты оттачивают умение рассчитывать свою речь на конкретного слушателя, отбирать и использовать для этого нужные речевые средства.

Задание 3. «Произнесение подготовленного убеждающего выступления». Это задание дается на дом, на выбор предлагается перечень тем, сформулированных преподавателем с учётом интересов (или специальности) учащихся и содержащих точно и конкретно выраженную точку зрения, с которой студент 
может соглашаться или спорить. Если в группе присутствуют иностранные студенты, то желательно учитывать релевантность тем и для их культуры.

Студенты должны обобщить и использовать все знания, навыки и умения, приобретенные в ходе курса (умение адаптировать тему выступления для конкретной аудитории, разработать и подать её; умение правильно составить текст с чёткой и ясной композицией, оригинальным и интересным содержанием; умение грамотно использовать невербальные средства общения (голос, темп, паузы, жесты, поза, мимика и т.д.); умение писать текст, исходя из целей, которые нужно достичь своим выступлением, и т.д.).

Время выступления - 2 минуты, если группа очень большая - 1,5 минуты, но не менее 1. Читать с листа запрещается, равно как и подглядывать в него. Также преподаватель может проверить самостоятельность написания текста: после практического занятия все тексты в электронном виде отправляются старосте, а тот формирует архив и направляет преподавателю. После проверки текстов на плагиат оценка за выступление либо подтверждается, либо аннулируется.

Также по согласованию со студентами можно сделать аудио- или видеозапись их выступлений и отправить для анализа после занятия.

Четвёртый блок завершает цикл подготовки оратора, его задачи - научить составлять и произносить логичный и понятный текст для аудитории разных видов, способствовать формированию аналитического мышления, показать тесную связь навыков, формируемых дисциплиной, с последующей профессиональной деятельностью.

Блок 5. «Завершающий этап - самооценка достигнутого уровня риторической компетенции»

Цель последнего блока - подвести итоги курса. Важно, чтобы студенты самостоятельно оценили свой уровень риторической компетенции. Самоанализ итогов курса можно провести и на круглом столе. Каждый студент готовит краткое сообщение, в котором отражает: свои основные достижения и недоработки в курсе (на основании составленного в самом начале графика), самое полезное упражнение для себя и стратегию дальнейшего развития ораторских навыков. Также студенты, основываясь на уже полученном ораторском опыте, обсуждают и совместно формулируют 10 советов начинающему оратору. Преподаватель фиксирует основные положения, особо отмечая, какие советы ставятся на первые 5 позиций (самые важные).

Эта форма работы позволяет учащимся обобщить и осмыслить полученный теоретический и практический материал, приучить себя к мыслительной дисциплине и постоянному анализу проделанной работы и выработать индивидуальную образовательную траекторию.

За информацией о дополнительных пособиях, посвященных нужному аспекту риторики, студент может обратиться к рабочей учебной программе дисциплины, размещенной в электронной образовательной сети вуза (для ДВФУ - это система Blackboard), а затем и в электронную библиотеку университета.

Еще одним вариантом завершения курса является риторический турнир. Подобные мероприятия проводились авторами статьи со студентами разных направлений одной школы (института), нескольких школ, университета. В процессе подготовки к риторическому турниру даже изначально не очень активные студенты смогли проявить себя и продемонстрировать положительные изменения уровня риторической компетенции.

Итак, представленная методика является результатом длительного педагогического поиска авторами оптимального способа построения универсального курса риторики, который можно было бы легко адаптировать для студентов разных направлений и уровня подготовки. Блочная модель построения дисциплины, включающая 5 частей (диагностика, анализ невербальных сигналов, умение строить и произносить подготовленные и импровизационные выступления, совершенствование и закрепление риторических навыков, рефлексия и оценка), позволяет 1) студентам: постепенно наращивать и эффективно закреплять знания, умения и навыки, что ведет к формированию устойчивых риторических компетенций; повысить мотивацию и активно использовать возможности, предоставляемые электронно-информационной образовательной средой вуза; формировать собственную образовательную траекторию для дальнейшего совершенствования ораторских навыков; 2) преподавателям: достаточно легко приспосабливать курс без значительного изменения его концепции к определяемому учебным планом количеству учебных часов, к наполняемости группы и разному уровню подготовки учащихся, а также иметь возможность контролировать уровень текущего освоения дисциплины студентами и в результате оперативно изменять последовательность и содержательное наполнение занятий. Таким образом, изучение риторики в вузе (как отдельным курсом, так и в качестве модуля в составе других лингвистических дисциплин) является важным инструментом формирования личности будущего специалиста. Описанная в данной статье методика преподавания риторики была многократно апробирована и показала хорошие результаты. По итогам анонимного тестирования, проводимого авторами в конце каждого курса, выявлено, что студентам было интересно заниматься риторикой и они собираются и дальше совершенствовать свои ораторские навыки.

Список источников

1. Баландина Л. А., Кураченкова Г. Ф. Риторическая компетенция как основа эффективной деятельности преподавателя вуза // Гуманитарные науки. 2012. № 4. С. 102-108.

2. Богданова Л. Ф., Пономарева Т. Л. Из опыта преподавания риторики на специальности «Связи с общественностью» // Записки Горного института. 2005. Т. 160. Ч. 1. С. 125-126.

3. Ваджибов М. Д. «Дневник ритора» для дагестанской студенческой аудитории (из опыта работы в Дагестанском государственном университете) [Электронный ресурс]. URL: https://cyberleninka.ru/article/n/dnevnik-ritora-dlya-dagestanskoystudencheskoy-auditorii-iz-opyta-raboty-v-dagestanskom-gosudarstvennom-universitete (дата обращения: 14.08.2019). 
4. Введенская Л. А., Павлова Л. Г. Риторика и культура речи. Ростов н/Д: Феникс, 2012. 538 с.

5. Волков А. А. Основы риторики: учебное пособие для вузов. М.: Академический проект, 2005. 304 с.

6. Горобец Л. Н. Риторическая компетенция учителя: проблемы исследования и практика формирования // Известия Российского государственного педагогического университета им. А. И. Герцена. 2008. № 62. С. 214-218.

7. Далецкий Ч. Б. Формирование риторической компетенции студента в современном вузе // Культурное наследие России. 2013. № 3-4. С. 59-65.

8. Егоренкова Н. А. Интеграция риторики и функциональной стилистики в практике преподавания курса «Русский язык и культура речи» в техническом вузе // Записки Горного института. 2005. Т. 160. Ч. 1. С. 176-178.

9. Кожина М. Н. Стилистический энциклопедический словарь. М.: Флинта; Наука, 2006. 696 с.

10. Марченко О. И. Основы красноречия. Риторика как наука и искусство убеждать. М.: Форум, 2016. 208 с.

11. Носкова Л. Г. Педагогический анализ эффективности преподавания профессионально ориентированной риторики // Труды Академии управления МВД России. 2013. № 2 (26). С. 69-73.

12. Стернин И. А. Практическая риторика. М.: Академия, 2008. 272 с.

13. Стешов А. В., Злыгостева М. Н. Методика преподавания риторики с помощью интеллект-карт // Мир русского слова. 2010. № 1. С. 78-85.

14. Тимонина И. В. К вопросу о месте риторики в системе гуманитарного знания // Вестник Оренбургского государственного университета. 2005. № 6. С. 29-34.

15. Ухова Л. В., Зимина Л. И. Внедрение инновационных образовательных технологий в практику преподавания риторики студентам нефилологических специальностей // Ярославский педагогический вестник. 2015. № 6. С. 113-119.

16. https://www.youtube.com/watch?v=WzesxsRI5pE (дата обращения: 20.03.2018).

17. https://www.youtube.com/watch?v=xvblLoR3eqc (дата обращения: 20.03.2018).

18. https://www.youtube.com/watch?v=0vb6Jzw7Pqs (дата обращения: 20.03.2018).

\title{
RHETORIC IN MODERN HIGHER SCHOOL: METHODOLOGY FOR TEACHING STUDENTS OF DIFFERENT AREAS OF TRAINING
}

\author{
Otkidych Elizaveta Vadimovna, Ph. D. in Philology \\ Mal'tseva Ol'ga Nikolaevna \\ Kiseleva Mariya Sergeevna, Ph. D. in Philology \\ Far Eastern Federal University, Vladivostok \\ vadimovna001@yandex.ru; olgapin_2004@mail.ru; liasic@list.ru
}

\begin{abstract}
The article introduces the authors' methodology of teaching rhetoric to students of different areas of training. The paper provides a detailed description of educational modules and sets of exercises for learners with different levels of communicative competence. The authors emphasize the versatility of the proposed teaching aid: it can be used as an autonomous course of rhetoric or as one of the modules; a teacher can extend the tasks, vary the task sequence depending on learning goals and his individual style. The possibility for the proposed methodology integration into informational educational environment of higher school is considered.
\end{abstract}

Key words and phrases: rhetoric; communication; teaching methodology; communicative competence; individual educational trajectory; electronic informational educational environment.

УДК 378

https://doi.org/10.30853/filnauki.2019.9.84

Дата поступления рукописи: 20.06.2019

На сегодняшний день конкурентным преимуществом на рынке труда становится наличие у сотрудников «мягких» навыков. Работодатели указывают на неудовлетворительный уровень межличностных, коммуникативных и аналитических способностей выпускников. Владение «мягкими» навыками имеет особую значимость для специалистов в области международных отношений. Большим потенциалом в формировании sоft skills обладает дисииплина «Иностранный язык». В связи с этим предлагается включить в иноязычную подготовку студентов-международников методическую систему по формированию «мягких» навыков. В статье рассматривается понятие «мягкие» навыки, выделены две группы «мягких» навыков, актуальных для профессионалов в области международных отношений, предложена методика формирования этих навыков.

Ключевые слова и фpaзы: мягкие навыки; эмоциональный интеллект; международные отношения; иностранный язык; межкультурная компетентность.

Слезко Юлия Викторовна, к. пед. н.

Дальневосточный федеральный университет, г. Владивосток

YuliaSlezko@mail.ru

\section{ФОРМИРОВАНИЕ «МЯГКИХ» НАВЫКОВ \\ В ПРОЦЕССЕ ПРОФЕССИОНАЛЬНО ОРИЕНТИРОВАННОГО ОБУЧЕНИЯ ИНОСТРАННОМУ ЯЗЫКУ СТУДЕНТОВ-МЕЖДУНАРОДНИКОВ}

На сегодняшний день владение только лишь профессиональными навыками и умениями недостаточно для осуществления эффективной трудовой деятельности. Конкурентным преимуществом в эпоху информатизации 